\title{
AC 2009-1115: COURSE LEARNING OUTCOMES AND STUDENT EVALUATIONS: CAN BOTH BE IMPROVED?
}

\section{Zbigniew Prusak, Central Connecticut State University}

Dr. Prusak is a Professor in the Department of Engineering at Central Connecticut State University in New Britain, CT. He teaches courses in Mechanical Engineering, Manufacturing Engineering Technology and Mechanical Engineering Technology programs. He has over 10 years of international industrial and research experience in the fields of precision manufacturing, design of mechanical and manufacturing systems and metrology. Dr. Prusak received M.S. Mechanical Engineering from Technical University of Krakow and his Ph.D. in Mechanical Engineering from University of Connecticut. E-mail: PrusakZ@ccsu.edu 


\title{
Course Learning Outcomes and Student Evaluations - Can Both Be Improved?
}

\begin{abstract}
This paper describes successful and unsuccessful activities used in engineering technology courses, as well as the relation of these activities to student learning and evaluation of their knowledge. The information presented is based on fifteen years of systematic student evaluations of engineering technology courses. The course evaluations were designed specifically to target areas of interest from the perspectives of learning outcomes and student perceptions. Relationships between learning outcomes and various course activities are correlated using Quality Function Deployment. As these activities should take advantage of various learning styles, they are related to concepts of Multiple Intelligences. The successes and failures of some of these activities are evaluated based on input from student course evaluations and faculty observation. Usefulness of typical questions asked on student evaluations is examined along with a list of major problems with student evaluations. Practical suggestions for developing personal, outcomes-oriented course evaluations are given with a list of useful questions that require more fact-based answers and are less affected by students' perceptions. A list of successful and unsuccessful course activities, including the ever subjective issue of grading is provided. A simple validation tool for student evaluations is also proposed.
\end{abstract}

\section{Introduction}

Student evaluations of teaching have been investigated extensively, especially in the past three decades and reported in hundreds of publications. Reliability, validity and bias have been reported with varying conclusions, and usefulness of the evaluations, or their certain parts, has been both acknowledged and questioned. Prevailing common sense beliefs among faculty often contradict these conclusions, and many engineering educators can show their own data supporting and questioning general conclusions from evaluations. Several studies cited by Dee ${ }^{1,2}$ show little to no relationship between course workload and faculty performance rating or overall course quality. However, a relationship or lack thereof does not imply causation. In her studies she assumes that student evaluations represent their opinions reliably and validly. That is still a long way from a true representation of the actual quality of the course. Perceptions about a fact, especially when expressed by people who are not yet qualified to make sound judgments, has a limited validity or none at all. That brings an issue of which questions from an evaluation of faculty and a course the students are really prepared to answer?

Ponton et al. wrote that "theories of cognitive motivation assert that to provide maximum selfmotivation, specific and challenging goals should be adopted that, if accomplished, will lead to personally satisfying outcomes" ${ }^{3}$. Student evaluations of faculty and courses tend to be a measure of satisfaction - a notoriously inconsistent and ever changing metric.

However, the basic questions are:

(1) a measure of satisfaction with what?

(2) how does it truly relate to what the said evaluations are supposed to measure? 
A very tangible outcome of taking a series of academic courses in a discipline (or even a single course) is students' continued pursuit of the discipline. According to Ponton et al., students tend to stop pursuing studies in engineering if they perceive that they are not capable based on experiences in courses taken to date ${ }^{3}$. Rationally or not, struggles, failures and unmet expectations in most recent courses taken weigh the most in such decisions.

Different course activities that promote active, collaborative, cooperative and problem-based learning in engineering have been shown to have positive input on learning outcomes. Improved academic performance, attitudes, student engagement and retention were reported by Prince 4 . Variety of course activities not only mimics the professional activity of most engineers, but also, intentionally or not, addresses different styles of learning preferred by individual students. These styles and preferences can be related to the Theory of Multiple Intelligences (MI) proposed in 1983 by Howard Gardner ${ }^{5,6}$; their relation to student evaluations is described later in the paper. Kotys et al. ${ }^{7}$ studied impact of interactivity in the engineering classroom on student performance and attitudes in course the Manufacturing Processes and Systems, a required senior level course in mechanical engineering. Their approach to creating different levels of active learning was to use different levels of interactions that take place in classroom and laboratory. The three levels of interaction used were: low-level interactivity, mid-level interactivity, and high-level interactivity, corresponding respectively to the following types of personal interaction: learnerteacher, learner-content and learner-learner. The higher the level of interactivity the more active and responsible for knowledge acquisition students have to be. Detailed descriptions of in-class and out-of-class activities and assignments are provided in the paper. Lecture, exams and other traditional classroom techniques form the structure of low-level interactivity, whereas high-level interactivity allocates less time to them and includes, among others, debates and brainstorming. Among different findings reported is no influence of level of interactivity on grades among males, and positive influence among females. Student evaluations show that the higher the level of interactivity the higher the student confidence in material learned and increase in level of interest. Also, classroom attendance, course rating, instructor rating, instructor effectiveness correlate positively with increased level of interaction.

Maccariella sums up results of several years of student evaluations in civil engineering senior level design ${ }^{8}$. The course was developed to address "serious concerns" over preparedness of engineering graduates published in a report by National Research Council (NRC) and concurred by the American Society of Civil Engineers (ASCE). Several years of student evaluations show consistently higher scores for adjunct faculty when compared with this course taught by full time faculty (although available data is for one faculty in each group only). "Therefore, it is believed that adjunct instructors' practical experience and knowledge of day-to-day operations of engineering projects effectively supplements the traditional engineering curricula." Based on my personal experience as a practicing engineer and engineering educator this belief has a lot of merit, because:

(1) most students want to identify themselves with practicing engineers,

(2) academic environment is all too often defined by faculty with solid scientific background but marginal, if any, engineering field experience,

(3) engineering practice tends to find simplest (mathematical) tools to complete a task,

(4) full time faculty insist on use of advanced scientific techniques in solving a problem. 
That said, it may be advantageous to have certain courses, such as senior project, taught by practicing engineers, as reflected on these evaluations. On the other hand, the well documented fact from student evaluations of adjuncts giving higher final grades than full time faculty remains unaddressed in that paper. However, the paper also cites a very frightening statistics from the ASCE Body of Knowledge report ${ }^{9}$ that " 98 percent of students switching from engineering to another major cited poor teaching as a reason for their departure". Blame one's failure on teacher; not on one's performance? Although "poor teaching" is a very loose category, hence not a specific question, such a uniformity of response among underperforming group cannot be ignored.

\section{Multiple Intelligences and Their Implications}

\section{Multiple Intelligences}

The theory of Multiple Intelligences (MI) was originally developed in 1983 by Howard Gardner. It suggests that the traditional IQ-based description of intelligence is not adequate to describe human potential. Gardner proposes nowadays 8 different intelligences to account for a broader range of human potential in children and adults.

Table 1. List of Multiple Intelligences versus areas of excellence of typical engineering and technical minds.

\begin{tabular}{|l|l|c|c|}
\hline \multicolumn{1}{|c|}{ Intelligence type } & \multicolumn{1}{c|}{ Description } & \multicolumn{2}{c|}{$\begin{array}{c}\text { Where technical minds excel } \\
\text { primarily (1) and secondarily (2) }\end{array}$} \\
\cline { 3 - 4 } & & Engineer & Technologist \\
\hline Linguistic & word smart & 2 & 2 \\
\hline Logical-mathematical & number/reasoning smart & 1 & 2 \\
\hline Visual-Spatial & picture smart & 1 & 1 \\
\hline Bodily-Kinesthetic & body and movement smart & 2 & 1 \\
\hline Musical & music, auditory smart & & \\
\hline Interpersonal & people smart, socially smart & & \\
\hline Intrapersonal & self reflection smart & 2 & 2 \\
\hline Naturalist & nature smart, surrounding smart & 2 & \\
\hline
\end{tabular}

\section{Multiple Intelligences and Various Learning Styles}

Gardner says that western culture and its schooling traditions focus mostly on linguistic, logicalmathematical intelligences and, to a certain extent, on visual intelligence. Therefore, there is a lot of untapped potential in additional ways of educating future engineers and engineering technologists. Accepting the existence of different intelligences shatters the centuries-old scholastic assumption that everybody can and should learn the same material in the same way. The answer to effective education of various individuals seems to be the introduction of variety of learning activities in order to give everyone a chance to excel. 


\section{Various Learning Styles and Course Activities}

Preference of various learning styles by individual learners can be catered to by drifting away from typical scholastic activities: lecture - reading - theory-reinforcing calculation exercises examination. The 21 learning activities listed in Table 2 can address most of the eight MI. Course evaluations will be undoubtedly more favorable if every student finds his/her favorite niche activities during the course.

\section{QFD for Defining Course Activities}

Quality Function Deployment (QFD) technique parallels engineering procedures used for examining specifications and performances of products and processes ${ }^{10,11}$. Developed in the 1970's in Japan and used in Kobe Shipyard of Mitsubishi Heavy Industries, QFD methodology stemmed from quality improvement tables and was originally used for development of new products ${ }^{12}$ (more details about past, present and future of QFD can be found in paper by Akao ${ }^{13}$ ). QFD is "the only comprehensive quality system aimed specifically at satisfying the customer" ${ }^{14}$. Ultimate customers in the case of academia are employers, but short term immediate customers are the students whose opinions (voices) are captured on course evaluations. QFD uses voice of customer (VOC) and technical characteristics of a product or process as inputs. Using these two groups of inputs: VOC called also Wants or Needs or Whats and technical characteristics called also Hows, QFD study establishes relationships between the two groups. Strength of each relationship between each Want and each How is assessed according to degree of how a customer's want is influenced by a technical characteristic. More detailed descriptions can be found in references ${ }^{10-15}$. Prusak described use of QFD in assessment of course activities for learning outcomes in 5 sophomore, junior and senior courses in Manufacturing and Mechanical Engineering Technology programs plus industrial co-op ${ }^{15}$.

Materials Processing

Geometric Dimensioning \& Tolerancing

Computer Aided Planning

Manuf. Process Planning and Estimating

Design for Manufacture

Industrial Co-op classroom / lab

classroom

classroom / computer lab

classroom / lab on occasion

classroom / lab on occasion

industry, full time
Sophomore

Junior/Sophomore

Junior

Senior

Senior

Senior

One of the key points of the analysis is that the Wants are knowledge and skills wanted by employers; not perceptions expressed by students. These Wants are established by engineering faculty, Industrial Advisory Board (IAB), accreditation agency, and discipline-related professional societies. However, students have input on how the knowledge is transferred to them and their skills developed in the course of the study because they are the immediate customers here. 
Table 2. Learning activities assessed in QFD matrices presented in Tables 3, 4 and 5 below. Typical student level of liking of these activities based on author's own course evaluation questionnaires, and relationship to types Multiple Intelligences (MI) typically found to be well developed among engineering students (details in Table 1).

\begin{tabular}{|c|c|c|c|c|}
\hline $\begin{array}{c}\text { Act } \\
\#\end{array}$ & $\begin{array}{l}\text { Abbreviation code } \\
\text { used in QFD matrix }\end{array}$ & Learning activity used & $\begin{array}{l}\begin{aligned} \multicolumn{1}{c}{\text { Level of }} \\
\quad \text { liking }\end{aligned} \\
\mathrm{H}=\text { high } \\
\mathrm{M}=\text { moderate } \\
\mathrm{L}=\text { low }\end{array}$ & $\begin{array}{l}\begin{array}{c}\text { Relationship } \\
\text { to } \mathrm{MI}\end{array} \\
\mathrm{S}=\text { strong } \\
\mathrm{M}=\text { moderate } \\
\mathrm{W}=\text { weak }\end{array}$ \\
\hline 1. & Lect & Lecture & $\mathrm{L}$ & W-M \\
\hline 2. & $\mathrm{Hw}$ & Graded homework & $\mathrm{M}$ & $\mathrm{S}$ \\
\hline 3. & Read & Reading and self study & L-M & $\mathrm{M}$ \\
\hline 4. & Quiz & Short quiz & L-M & W-S \\
\hline 5. & Exam & Exam (midterm, final, etc.) & L-M & $\mathrm{W}-\mathrm{S}$ \\
\hline 6. & Comp Lect & Computer lab lecture & M-H & $\mathrm{S}$ \\
\hline 7. & Lab Sh Exe & Laboratory hands-on short exercises & $\mathrm{H}$ & S \\
\hline 8. & Lab Expm Team & Laboratory experimentation - team work & $\mathrm{H}$ & $\mathrm{S}$ \\
\hline 9. & Forens Indiv & $\begin{array}{l}\text { Forensic analysis in-class exercises - } \\
\text { individual work }\end{array}$ & M & $S$ \\
\hline 10. & Forens Team & $\begin{array}{l}\text { Forensic analysis in-class exercises - team } \\
\text { work }\end{array}$ & $\mathrm{H}$ & $S$ \\
\hline 11. & Des Sh Exe Indiv & $\begin{array}{l}\text { Design short exercises in-class - individual } \\
\text { work }\end{array}$ & L-M & $S$ \\
\hline 12. & Des Sh Exe Team & $\begin{array}{l}\text { Design short exercises in-class - team } \\
\text { work }\end{array}$ & $\mathrm{H}$ & $S$ \\
\hline 13. & Des Proj Indiv & Design projects - individual work & M & $\mathrm{S}$ \\
\hline 14. & Des Proj Team & Design projects - team work & $\mathrm{M}-\mathrm{H}$ & $\mathrm{S}$ \\
\hline 15. & Des Dev Lab Expm & $\begin{array}{l}\text { Design and development of new lab } \\
\text { experiments }\end{array}$ & $\mathrm{L}$ & $S$ \\
\hline 16. & Concept Gener & $\begin{array}{l}\text { Concept generation (Brainstorming, } \\
\text { Synectics) }\end{array}$ & $\mathrm{H}$ & $S$ \\
\hline 17. & Critique & Critique of own work and work of others & L-M & $\mathrm{M}-\mathrm{S}$ \\
\hline 18. & Info Search & $\begin{array}{l}\text { Information search and compilation } \\
\text { assignment }\end{array}$ & L-M & $\mathrm{M}-\mathrm{S}$ \\
\hline 19. & Pres Indiv & Individual presentation & $\mathrm{M}$ & W-S \\
\hline 20. & Pres Team & Group presentation & $\mathrm{M}$ & W-S \\
\hline 21. & Co-op excell & Industrial Co-op excellent experience & $\mathrm{H}$ & $\mathrm{M}-\mathrm{S}$ \\
\hline 22. & Co-op poor & Industrial Co-op poor experience & $\mathrm{L}$ & $\mathrm{W}-\mathrm{M}$ \\
\hline
\end{tabular}

Learning activities that are both highly liked by students $(\mathrm{H})$ and have strong relationship (S) to the types of Multiple Intelligences typically observed among engineering students (and engineering professionals) are highlighted in yellow. Comparing the list of the above highlighted learning activities to the lists of activities most useful in fulfillment of learning outcomes (Tables 3, 4 and 5); a large overlap is noticeable. A rhetorical question can be therefore asked: why not teach course material incorporating at least some of the activities that have the highest potential of resulting in good learning experiences and being naturally liked by the target student audience? 
Table 3. Comparison of usefulness of learning activities in fulfillment of learning outcomes for all 5 courses assessed. The higher the number the higher the usefulness ${ }^{15}$. Codes for Learning Activities are in Table 2.

\begin{tabular}{|c|c|c|c|c|c|c|c|c|c|c|c|c|c|c|c|c|c|c|c|c|c|c|}
\hline & \multicolumn{22}{|c|}{ Learning Activity } \\
\hline & 总 & 主 & 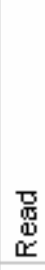 & 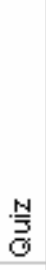 & $\begin{array}{l}\text { E } \\
\underset{\mathbb{W}}{\times} \\
\text { W }\end{array}$ & $\begin{array}{l}\text { 苞 } \\
\text { 号 } \\
\text { E }\end{array}$ & 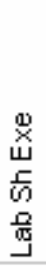 & 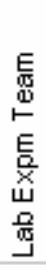 & 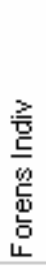 & 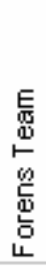 & 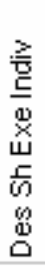 & 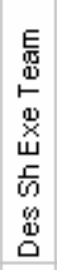 & 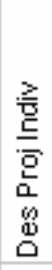 & 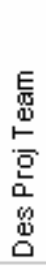 & 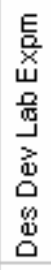 & 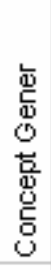 & 步 & $\begin{array}{l}\text { 동 } \\
\text { 愛 } \\
\text { 号 } \\
\text { 吕 } \\
\underline{\underline{E}}\end{array}$ & 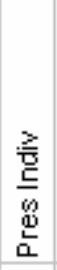 & 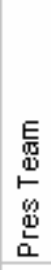 & 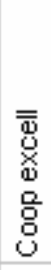 & $\begin{array}{l}\text { 总 } \\
\text { 응 }\end{array}$ \\
\hline & 1 & 2 & 3 & 4 & 5 & 6 & 7 & 8 & 9 & 10 & 11 & 12 & 13 & 14 & 15 & 16 & 17 & 18 & 19 & 20 & 21 & 22 \\
\hline $\begin{array}{l}\text { Learning Acitvity } \\
\text { Usefulness } \\
\text { Comparison }\end{array}$ & $\begin{array}{c}9 \\
15\end{array}$ & $\bar{\infty}$ & $\overline{\mathscr{9}}$ & $\bar{~} \bar{y}$ & $\begin{array}{l}5 \\
15\end{array}$ & $\overline{\overline{\mathscr{N}}}$ & $\stackrel{m}{\circ}$ & 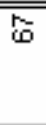 & $\bar{\sigma}$ & 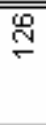 & "मे & $\bar{m}$ & $\bar{\sigma}$ & 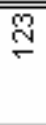 & 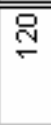 & 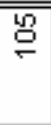 & 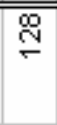 & 19 & $\stackrel{\varphi}{P}$ & $\bar{c}$ & 䎡 & 产 \\
\hline
\end{tabular}

The group of learning activities having highest usefulness in fulfillment of learning outcomes (taking into account 5 courses listed earlier in the paper and omitting Co-op since it is not controlled directly by university) consists of:

- Forensic analysis in-class exercises - team work

- Design projects - team work

- Design and development of new lab experiments

- Concept generation (Brainstorming, Synectics)

- Critique of own work and work of others

Table 4. Comparison of usefulness of learning activities used in senior level course Manufacturing Process Planning and Estimating in fulfillment of learning outcomes. The higher the number the higher the usefulness ${ }^{15}$. Codes for Learning Activities are in Table 2.

\begin{tabular}{|c|c|c|c|c|c|c|c|c|c|c|c|c|c|c|c|c|c|c|c|c|c|c|}
\hline & \multicolumn{22}{|c|}{ Learning Activity } \\
\hline & 总 & 辛 & $\begin{array}{l}\underset{\mathbb{W}}{\mathbb{W}} \\
\underset{\mathbb{1}}{\mathbb{E}}\end{array}$ & 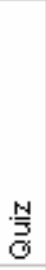 & $\begin{array}{c}\underset{\mathbb{W}}{\times} \\
\underset{w}{\Psi}\end{array}$ & 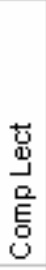 & 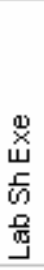 & 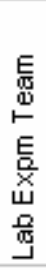 & 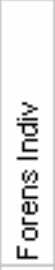 & 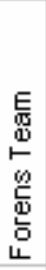 & 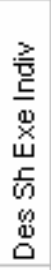 & 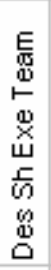 & 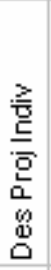 & 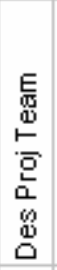 & 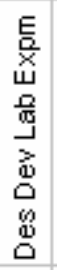 & 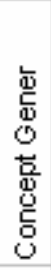 & 荘 & 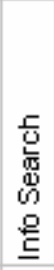 & 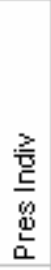 & 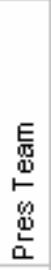 & 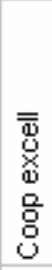 & $\begin{array}{l}\text { 음 } \\
\text { 응 }\end{array}$ \\
\hline & 1 & 2 & 3 & 4 & 5 & 6 & 7 & 8 & 9 & 10 & 11 & 12 & 13 & 14 & 15 & 16 & 17 & 18 & 19 & 20 & 21 & 22 \\
\hline & \multicolumn{22}{|c|}{ Level of emphasis in course } \\
\hline & $\bullet$ & 0 & $\bullet$ & $\Delta$ & $\bullet$ & & & & $\Delta$ & $\Delta$ & $\Delta$ & 0 & & $\bullet$ & $\Delta$ & $\bullet$ & $\Delta$ & $\bullet$ & $\bullet$ & & & \\
\hline & \multicolumn{22}{|c|}{ Bloom's Taxonomy level } \\
\hline & 1 & 2 & 1 & 1 & 2 & & & & 4 & 4 & 3 & 3 & & 6 & 5 & 5 & 5 & 3 & 3 & & & \\
\hline $\begin{array}{l}\text { Usefulness } \\
\text { Comparison of } \\
\text { Learning Acitvities } \\
\text { Used in Course }\end{array}$ & $\underset{\mathrm{N}}{ }$ & 品 & 志 & Y & 紧 & $\bar{O}$ & O & 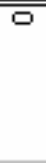 & $\bar{\sigma}$ & $\stackrel{\mathscr{P}}{\circ}$ & 零 & $\bar{~} \overline{0}$ & $\bar{O}$ & $\stackrel{\text { 点 }}{=}$ & $\stackrel{\stackrel{\rho}{\circ}}{\circ}$ & 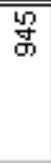 & $\stackrel{\mathrm{g}}{\mathrm{N}}$ & $\begin{array}{l}19 \\
5 \\
5\end{array}$ & 志 & $\overline{0}$ & O & 10 \\
\hline
\end{tabular}


Table 5. Comparison of usefulness of learning activities used in senior level course Design for Manufacture in fulfillment of learning outcomes. The higher the number the higher the usefulness ${ }^{15}$.

Codes for Learning Activities are in Table 2.

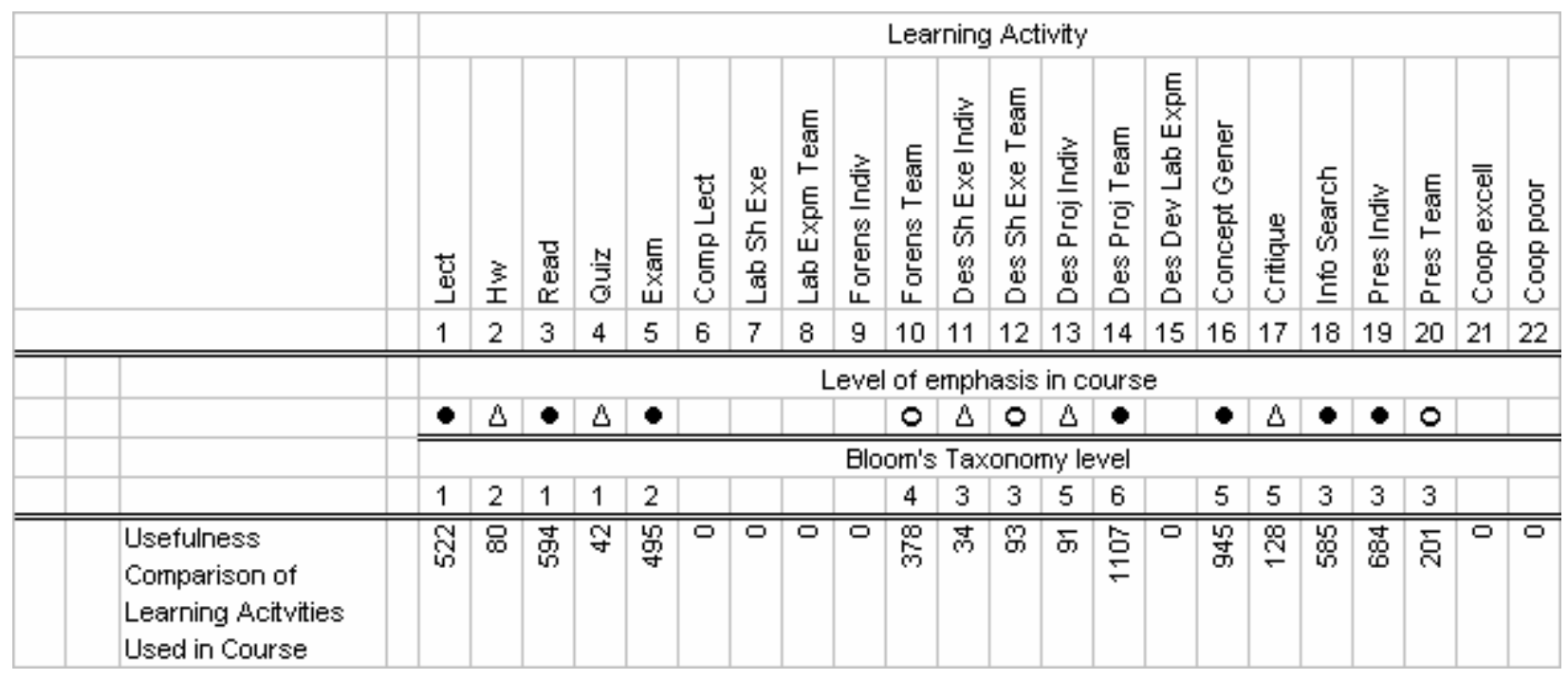

Based on scores in the bottom row of Tables 4 and 5, the group of learning activities having highest usefulness in fulfillment of learning outcomes in these two senior level courses consists of:

- Design projects - team work

- Concept generation (Brainstorming, Synectics)

- Individual presentations

- Reading

- Information search

Worth noting is that for the two senior level courses (Tables 4 and 5), the group of the most useful learning activities coincides with typical activities of practicing engineers. Student evaluations show that all students like unrestrictive and all-permissive aspects of concept generation (brainstorming), but have problems with more methodical parts of it. Team work on design projects, individual presentations and information search are not universally liked by the students when expectation of quality deliverables is strictly implemented and work haphazardly put together is graded low. The validity of certain parts of student evaluations is simply not there (evaluators are in process of learning a subject and are not yet qualified enough to make a solid judgment about the subject).

Similar conclusion can be drawn in the case of 5 sophomore to senior courses examined together (Table 3). Forensic analysis as well as critique of own work and work of others, although very useful and fun to do at the beginning, can be frustrating for inexperienced students. Dissatisfied students are likely to give low evaluation rating for such course, and to instructor who insists on providing a quality work. 


\section{Questions Asked on Student Evaluations and Their Usefulness}

Based on years of consistent course evaluations, typical questions on evaluation questionnaires are fairly useless in providing feedback to faculty willing to continuously improve courses and to program coordinators looking for ways to improve program learning outcomes. This is because most of them are administrative questions that are answered based on perceptions and feelings. Such enquiry is not precise enough to get answers based on facts. For the most part, they are far from enquiring about course activities and fulfillment of learning outcomes - which are things most useful in continuous improvement of the course, provide assessment and accreditation data, and are the backbone of quality education.

\section{Biggest Problems with Student Evaluations}

The author of this paper used his own course evaluation questionnaires prepared with tips listed below. After well over a hundred courses evaluated, some typical problems need to be recognized with using a typical questionnaire developed by university administrators. They are:

- Inconsistency of answers

- Lack of logic (carelessness) demonstrated by pattern in student's answers or bubble sheet markings

- Totally wrong answers to simplest questions showing student's carelessness or incompetence:

- Were you provided with course syllabus?

- Did the syllabus contain course outline, due dates of assignments?

- Was a written explanation of course grading policy distributed at the beginning of the course?

- Was an explanation of course attendance policy distributed at the beginning of the course?

- Were any classes in the course ever cancelled?

- Was it possible for you to make comments, ask questions or express ideas in class?

- What is your student status?

- Is the course required in your major or an elective?

Another group of problematic questions are those belonging to the fuzzy, perception-based category:

- Were class meetings intellectually stimulating?

- Does your experience in class make you want to learn more about this subject?

- Would you rate the quality of instruction in this course as high, relatively high, medium, ......?

- Would you rate the overall quality of this course as high, relatively high, medium, .....?

There is always room for evaluations being swayed by personal likes and dislikes of a respondent, but that category is too broad and topic too elusive to be even touched in this paper. Has anyone not seen a student who was friendly, tried to get a good grade, but after completely botching an assignment became openly hostile and preoccupied with finding who to blame?

The biggest problems with overall outcome of student evaluations are:

1. with exception of very bad and very good courses and instructors, typical administrative evaluations do not provide almost any useful information that can be used for quality improvement of courses, programs and departments

2. qualitative answers which are not even on nominal scale are turned into numbers, or a single number when course evaluation is statistically processed 
3. various meaningless statistics are calculated, resulting numbers are fed into a rubric and an overall conclusion is drawn

4. no validation of student evaluations displaying inconsistent, illogical and wrong answers

5. no association of student answers and overall evaluations with their course performance (for example with final grade, or better yet, with grades from major deliverables)

6. no explanation attempted to find out reasons for outlying answers

7. no explanation attempted to find out reasons for great comments and very bad comments about course or about instructor

8. student perception of what knowledge and skill they should learn is often far removed from reality they will be facing after graduation, hence the evaluator (student) is not qualified to answer some questions

Do I advocate switching from anonymous evaluations to signed ones, made unavailable to faculty for at least few months? That would not be an ideal solution. Although a lot more administrative work would be needed, at least the major problems described above could be overcome.

One thing is rather simple to do - plotting evaluation statistics from each individual evaluation done by a student against final grade of that student. Just like in real engineering world, outliers may tell a lot more than averages. If poor evaluation correlates with poor grade, blame should not be spread, but a reason for student's failure should be found.

\section{Practical Suggestions - Path of Useful Enquiry}

\section{Questions}

It is suggested that each faculty develop his/her own student evaluation questionnaire having multiple choice answers plus space for comments.

The questionnaire should contain questions pertaining to and evaluating the following:

1. how the class was run

2. efficiency of using class time

3. methods used for instruction

4. any course activity considered "boring"

5. attitude towards group work

6. usefulness of textbook(s) used for class

7. usefulness of other instructional materials used for class (handouts, web, overheads, PowerPoint slides, videos, etc.)

8. software used in class

9. helpfulness of homework assignments in learning and understanding course material

10. load of homeworks, exams, individual projects, group projects, presentations, and other easily identifiable deliverables

11. level of difficulty of the above course deliverables

12. weight of the above course deliverables on final grade

13. pace of lecturing

14. pace of in-class problems solving

15. balance between theory and practice (problems, exercises, projects)

16. grading (harsh / easy)

17. fairness of grading 
18. consistency of grading

19. overall difficulty of course material

20. list of topics covered in order to identify which ones were conceptually easy or difficult to understand

21. efficiency of learning course material defined as understanding of a topic per time spent learning it

22. efficiency of completing course deliverables defined as new knowledge and skills acquired per time spent

23. new methods of solving "real-world problems"

24. helpfulness of instructor's work in classroom

25. availability of instructor for individual consultation

26. meeting student's expectations about the course

27. worthiness of taking the course

\section{Written Comments}

At the end there should be room for comments:

1. suggested changes to:

- class scheduling

- office hours scheduling / availability for individual consultation

- teaching methods used for instruction

- classroom activities

- course deliverables

- work load needed to succeed in the course

- textbooks

- handouts and other instructional materials

- software used

- assignments

- due dates

- grading

- expectations about the course

2. suggested deletions

3. suggested additions

If a student has no comments, there should be a provision to encircle a statement that no changes are needed.

\section{Questions Targeting Fulfillment of Learning Outcomes}

From the list of 30 desired learning outcomes (knowledge, abilities and skills) that were assessed by Prusak ${ }^{15}$ for their relevance to learning activities fulfillment, almost all of them can be enquired about on student evaluations.

The questions can be phrased as follows:

- While taking this course, did you improve your engineering and scientific knowledge base? 
- While taking this course, did you improve your task-oriented understanding of engineering and scientific knowledge base?

- While taking this course, did you have to solve problems in teams?

- While taking this course, did you improve your team work skills?

- While taking this course, were you instructed how to search for information?

- While taking this course, were you expected to search for information, reduce it and compile?

- Etc.

Again, specific questions related to fulfillment of specific learning outcomes, not merely expressing one's general feelings and perceptions.

Table 6. List of program learning outcomes that can be used to enquire about the value of attending a course (based on ${ }^{15}$ ).

\begin{tabular}{|l|l|}
\hline LO \# & \multicolumn{1}{|c|}{ Desired learning outcome (knowledge, abilities and skills) } \\
\hline \hline 1. & Engineering and scientific knowledge base \\
\hline 2. & Task-oriented understanding and use of engr. and sci. knowledge base \\
\hline 3. & $\begin{array}{l}\text { Knowledge and use of computer tools (CAD/CAM, FEA, data acquisition, data processing and } \\
\text { graphing, reporting, presentation, etc.) }\end{array}$ \\
\hline 4. & Ability to quickly generate hand sketches \\
\hline 5. & Knowledge of pertinent engineering standards \\
\hline 6. & Task-oriented understanding and use of pertinent engineering standards \\
\hline 7. & Interdisciplinary thinking \\
\hline 8. & Systematic and interdisciplinary evaluation of problems \\
\hline 9. & Analysis of well-defined problems \\
\hline 10. & Analysis of open-ended problems \\
\hline 11. & Analysis of ill-defined problems \\
\hline 12. & Solving of problems in teams \\
\hline 13. & Organization of team work \\
\hline 14. & Acting independently \\
\hline 15. & Self-organization \\
\hline 16. & Written communication with technical people \\
\hline 17. & Verbal communication with technical people \\
\hline 18. & Written communication with non-technical people \\
\hline 19. & Verbal communication with non-technical people \\
\hline 20. & Communication with people from different cultures \\
\hline 21. & Persuasion, negotiation \\
\hline 22. & Search for information \\
\hline 23. & Reduction and compilation of information \\
\hline 24. & Creative thinking \\
\hline 25. & Systems thinking \\
\hline 26. & Value engineering \\
\hline 27. & Professional ethics \\
\hline 28. & Personal manners \\
\hline 29. & Work under pressure \\
\hline 30. & Self learning \\
\hline & \\
\hline
\end{tabular}




\section{Conclusions}

Development of more realistic course evaluations should be driven by tangible and measurable educational goals for an academic course. Same evaluation questionnaire is of little value in measuring student learning and satisfaction in a course. Practical suggestions in developing course evaluations targeting fulfillment of learning outcomes through specific questions and comments are included in the paper. Through QFD study of program learning outcomes and learning activities certain activities proved to be the most universal activities in developing a wide range of professional skills for sophomore to senior students in Manufacturing ET and Mechanical ET programs. These are: design projects done in teams, concept generation, individual formal presentations, information search, compilation and reduction, as well as forensic studies.

Preference of various learning styles by individual learners can be catered to by shifting away from typical scholastic activities and using learning activities that cover Multiple Intelligences. The wide range of course activities is expected to result in better fulfillment of learning outcomes through more inclusive learning and in better course evaluations.

\section{Bibliography}

1 Dee, K.C., Student Perceptions of High Course Workloads are Not Associated with Poor Student Evaluations of Instructor Performance, Journal of Engineering Education, vol.96, no.1, 2007, pp.69-78.

2 Dee, K.C., Reducing Workload in Your Class Won't "Buy" Your Better Teaching Evaluation Scores: ReRefutation of a Persistent Myth, Proceedings of ASEE Annual Conference, June 20-23, 2004, Salt Lake City, UT.

3 Ponton, M., Edmister, J.H., Ukeiley, L.S., Seiner,J.M., Understanding the Role of Self-Efficacy in Engineering Education, Journal of Engineering Education, vol.90, no.2, 2001, pp.247-251.

4 Prince, M., Does Active Learning Work? A Review of the Research, Journal of Engineering Education, vol.93, no.3, 2004, pp.223-231.

5 Gardner,H., Frames of Mind: The Theory of Multiple Intelligences. Basic Books, New York, NY, 2004.

6 Multiple Intelligence Theory by Howard Gardner http://www.multipleintelligencetheory.co.uk/ viewed on $01 / 15 / 2009$.

7 Kotys-Schwartz, D., Carlson, L., Reamon, D., Evaluation of the Impact of Interactivity on Student Performance and Attitudes in Engineering, Proceedings of ICREE - Inaugural International Conference on Research in Engineering Education, June 22-24, 2007, Honolulu, HI.

8 Maccariella, J, The Role of Adjuncts in Teaching ASCE's Body of Knowledge, Proceedings of ASEE Annual Conference, June 24-27, 2007, Honolulu, HI.

9 American Society of Civil Engineers, Body of Knowledge Committee on the Academic Prerequisites for Professional Practice. Civil Engineering Body of Knowledge for the 21st Century, Preparing the Civil Engineer for the Future, American Society of Civil Engineers, Reston, VA. 2004.

10 Hauser, J., Clausing, D., The House of Quality, Harvard Business Review, vol.66, no.3, 1988, pp.63-73.

11 Urban, G., Hauser, J., Design and Marketing of New Products, Prentice Hall, Englewood Cliffs, NJ, 1993.

12 ReVelle, J.B., Frigon, N.L., Jackson, H.R., From Concept to Customer, Van Nostrand Reinhold, 1995.

13 Akao, Y., QFD: Past, Present and Future, International Symposium on QFD, 1997, Linkopping, Sweden.

14 Japan Business Consultants, http://www.mazur.net/qfd.htm\#Design\%20for\%20Six\%20Sigma viewed on $12 / 12 / 2006$.

15 Prusak, Z., Use of QFD in Assessment of Course Activities for Learning Outcomes, Proceedings of ASEE Annual Conference, June 24-27, 2007, Honolulu, HI. 